\title{
Giving Breast Milk For Motoric Development For Babies In Karangtalun Village, Kalidawir District, Tulungagung On 2019
}

\author{
Farida* \\ STIKes Hutama Abdi Husada Tulungagung, Indonesia \\ *poprimf@gmail.com
}

\begin{abstract}
Babies are individuals with unique growth and development patterns, meaning they have a growth pattern and physical development. There are 4 components in development including rough and fine motor skills, language, and social person. Breast milk is a good nutrition for babies because it contains the nutrients needed. Giving Breast milk that is not optimal affects the motor development process. This study aims to determine the relationship between breast milk and motor development in infants aged 6-9 months in Karangtalun Village, Kalidawir District, Tulungagung Regency in 2019. The study design was a comparative study with an approach cross-sectional. The population used is all mothers who have babies aged 6-9 months. The research subjects were 61 infants aged 6-9 months in Karangtalun Village, Kalidawir District, Tulungagung Regency with a total sampling technique. Collecting data using a questionnaire sheet and DDST II. The data were processed using editing, coding, scoring, and tabulating techniques, then analyzed using the statistical test Chi-Square. The results of the study of 61 babies found that 16 babies (26\%) who received exclusive breast milk all had normal motor development. It was found that the majority of infants who received subtitute of breast milk had questionable motor development, namely rough motor skills of 33 babies $(54.1 \%)$ and fine motor skills of 26 babies (42.6\%). Both rough and fine motor skills were obtained with a value of $p=0.000$ and $\alpha=0.05$ which means value ( $p$-value $<\alpha$ ), meaning that there is a relationship between breast milk and motor development in infants aged 6-9 months in Karangtalun Village, Kalidawir District, Tulungagung Regency. In 2019. It was concluded that exclusive breast milk is one of the factors that can affect motor development because breast milk contains nutrients that help the motor development process so that it develops optimally. For this reason, it is necessary to increase information and counseling on the importance of exclusive breast milk as long as the baby is still aged 0-6 months so that it does not affect motor development.
\end{abstract}

Keywords: Infant, Breast milk, Motoric Development 


\section{STRADA Jurnal Ilmiah Kesehatan}

DOI: $10.30994 /$ sjik.v9i2.334

ISSN: 2252-3847 (print); 2614-350X (online)

Vol.9 No.2 November 2020 Page.1567-1574

\section{BACKGROUND}

One important aspect of development is motor development. Motor development is the beginning of intelligence and social emotions in children (Laksana, 2011). Motor development is the development of exercise control through the activity of the central nerves, peripheral nerves, and muscles. Movement control arises from the development of reflexes that begin at birth. Children become helpless if this development does not occur (Soetjiningsih \& Ranuh, 2013).

Motor development in infants is influenced by several factors, one of which is nutrition. Good nutrition for babies is breast milk. Breast milk is a liquid secreted by the mother's breast glands in the form of natural food or the best nutritious and high-energy milk produced since pregnancy (Wiji, RN 2013). Motor development is also influenced by breast milk which is not optimal.

In infants, the best food is exclusive breast milk because almost all substances needed by babies are contained there. Breast milk contains antibodies that are not found in formula milk, so it is the best choice for babies (Yuliarti, 2010). According to WHO (World Health Organization), exclusive breast milk is simply breast milk without being given other fluids, whether formula milk, water, lemon juice, or other additional foods until the baby is 6 months old. Before turning 6 months of age, the baby's digestive system is not functioning properly, so the baby is unable to digest food other than breast milk (Marimbi, 2010).

Breast milk has many benefits, some of which are increase the immune system of the baby, increase vision and speaking ability, increase intelligence, and reducing the risk of disease (diabetes, cancer in children, and the possibility of suffering from heart disease). Besides, exclusive breast milk makes babies develop well in the first six months until they are more than six months old (Haryono and Setianingsih, 2014). Exclusive breast milk affects development because the ingredients in breast milk are very good for development.

Research by Husniati, A (2007), the factors related to children's motor development, namely the length of breast milk, children's nutritional status, and per capita family income, showed that the length of breast milk affects children's development. So this also proves that exclusive breast milk can affect children's development.

Based on the results of research by Ali, et al (2014), children who were exclusively breastfed for 6 months or more had a higher ASQ (Ages and Stages Questionnaire) score with a p-value (0.004) in the rough motoric sector compared to children- children who do not get exclusive breast milk with p-value (0.091), so it can be concluded that exclusive breast milk plays an important role in child development, especially in the rough motoric sector. According to Wiji, RN (2013), 15 children who were exclusively breastfed had 93.8\% more fine motor development than those who were not exclusively breastfed with a percentage of $87.5 \%$ of 21 babies.

Many researches show breast milk is better than substitute of breast milk but people still use substitute of breast milk for their babies. The prevalence of exclusive breast milk in Indonesia is still low. According to the Ministry of Health's Data and Information Center 2017, exclusive breast milk in Indonesia is only 35\%. This figure is still far according the WHO (World Health Organization) recommendation of 50\%. In East Java, exclusive breast milk is based on $71 \%$ data (data from the East Java Health Office 2016). Based on a preliminary study conducted by researchers on December 122018 at the integrated service post, Karangtalun Village, Kalidawir District, there were 61 babies aged 6-9 months. From the 61 babies, the researchers took 10 samples from 10 babies and conducted interviews. From the interview results, it was found that 7 of 10 babies (70\%) did not receive exclusive breast milk. 


\section{STRADA Jurnal Ilmiah Kesehatan}

DOI: $10.30994 /$ sjik.v9i2.334

ISSN: 2252-3847 (print); 2614-350X (online)

Vol.9 No.2 November 2020 Page.1567-1574

Many factors cause exclusive breast milk is not optimal, due to factors of the mother herself, family support, economy, and formula milk producers. Exclusive breast milk is often constrained by the lack of knowledge of mothers about the importance of exclusive breast milk. The development of various formula milk products that provide a lot of nutritional content has greatly changed the patterns of feeding in children. In formula milk, the nutritional content is not perfect. Even though formula milk manufacturers try to match the nutritional content contained in breast milk, the results still cannot be the same, because the nutritional content in breast milk is easier for the baby's intestine to absorb.

Non-exclusive breast milk has a bad impact on the baby. This is in line with data from the World Health Organization (WHO) in 2005, approximately 1.5 million children died due to improper feeding. Less than $15 \%$ of infants worldwide are exclusively breastfed for less than 6 months and often unsafe and inappropriate complementary breast milk.

\section{METHODS}

Research design is very important in research, allowing maximum control of several factors that can affect the accuracy of a result (Nursalam, 2013).

This study used a comparative research design with approach cross-sectional, in which the researcher took measurements or observations at the same time (one time) between the independent variables (breast milk) and the dependent variable (motor development of infants aged 6-9 months) (Taufiqurrohman, 2009).

\section{RESULTS}

\section{RESEARCH RESULTS}

1. Breast milk in infants aged 0-6 months

Table 1. Distribution of the frequency of breast milk for infants aged 0-6 months in Karangtalun Village, Kalidawir District, Tulungagung Regency

\begin{tabular}{llll}
\hline No. & \multicolumn{1}{c}{ Breast milk } & Frequency & Percentage \\
\hline 1. & Exclusive & 16 & $26 \%$ \\
\hline 2. & substitute of breast milk & 45 & $74 \%$ \\
\hline & Total & 61 & $100 \%$ \\
\hline
\end{tabular}

Table 1 shows that most babies are given substitute of breast milk as many as 45 babies $(74 \%)$.

\section{Rough motor development in infants aged 6-9 months}

Table 2 Frequency distribution of rough motor development in infants aged 6-9 months in Karangtalun Village, Kalidawir District, Tulugagung Regency, 2019

\begin{tabular}{|c|c|c|c|}
\hline No. & Rough motor development & Frequency & Percentage \\
\hline 1. & Normal & 28 & $45.9 \%$ \\
\hline 2. & Doubtful & 33 & $54.1 \%$ \\
\hline & Total & 61 & $100 \%$ \\
\hline
\end{tabular}

Table 2 shows that most babies have doubtful rough motor development, as many as 33 babies (54.1\%). 


\section{STRADA Jurnal Ilmiah Kesehatan}

DOI: $10.30994 /$ sjik.v9i2.334

ISSN: 2252-3847 (print); 2614-350X (online)

Vol.9 No.2 November 2020 Page.1567-1574

3. Fine motor development in infants aged 6-9 months

Table 3 Frequency distribution of fine motor development in infants aged 6-9

months in Karangtalun Village, Kalidawir District, Tulugagung

Regency, 2019

\begin{tabular}{clll}
\hline $\begin{array}{c}\text { No } \\
\text {. }\end{array}$ & $\begin{array}{c}\text { Fine motor } \\
\text { development }\end{array}$ & Frequency & Percentage \\
\hline 1. & Normal & 35 & $57.4 \%$ \\
\hline 2. & Doubtful & 26 & $42.6 \%$ \\
\hline & Total & 61 & $100 \%$ \\
\hline
\end{tabular}

Table 3 shows that most babies have normal fine motor development, as many as 35 babies $(57.4 \%)$.

4. Giving Breast milk in Rough motor development and Fine motor in infants aged 69 months

Table 4 Cross-tabulation of breast milk in fine motor development in infants aged 6-9 months in the village of the District Karangtalun Kalidawir

Tulugagung Regency Year 2019.

\begin{tabular}{|c|c|c|c|c|c|c|c|c|c|c|c|c|}
\hline \multirow{3}{*}{ Breast milk } & \multicolumn{4}{|c|}{ Rugged Motor Development } & \multirow{2}{*}{\multicolumn{2}{|c|}{ Total }} & \multicolumn{4}{|c|}{ Fine Motor Development } & \multirow{2}{*}{\multicolumn{2}{|c|}{ Total }} \\
\hline & \multicolumn{2}{|c|}{ Normal } & \multicolumn{2}{|c|}{ Dubious } & & & \multicolumn{2}{|c|}{ Normal } & \multicolumn{2}{|c|}{ Dubious } & & \\
\hline & & $\mathrm{N} \%$ & & $\mathrm{~N} \%$ & & N\% & & $\mathrm{N} \%$ & $\mathrm{~N}$ & $\%$ & $\mathrm{~N}$ & $\%$ \\
\hline Exclusive & 16 & 100 & 0 & 0 & 16 & 100 & 16 & 100 & 0 & 0 & 16 & 100 \\
\hline $\begin{array}{l}\text { SUBTITUTE } \\
\text { OF BREAST } \\
\text { MILK }\end{array}$ & 12 & 26.7 & 33 & 73.3 & 45 & 100 & 19 & 42.2 & 26 & 57.8 & 45 & 100 \\
\hline Total & 28 & 45.9 & 33 & 54.1 & 61 & 100 & 35 & 57,4 & 26 & 42,6 & 61 & 100 \\
\hline $\begin{array}{l}\text { Chi-Square } \\
\text { Results }\end{array}$ & Test & $p$-value & .000 & & & & $\alpha=$ & & & & & \\
\hline
\end{tabular}

Table 4 above shows that of the 16 babies who were given exclusive breast milk, all babies had normal rough motor development, namely 16 babies (100\%), and of the 45 babies who were given substitute of breast milk there were only 12 babies (26.7\%) who had normal rough motor development. All babies who had normal fine motor development were 16 babies (100\%), while out of 45 babies who were given substitute of breast milk only 19 babies (42.2\%) had normal fine motor development.

The results of correlation analysis using the statistical test Chi-Square obtained $p$-value $=$ 0.000 , smaller than $\alpha=0.05$, so $\mathrm{H}_{0}$ is rejected, meaning that there is a relationship between breast milk and rough motor development in infants aged 6-9 months in Karangtalun Village, Kalidawir District, Tulungagung Regency

\section{DISCUSSION}

A. Giving breast milk in Karangtalun Village, Kalidawir District, Tulungagung Regency in 2019

Based on table 1 it can be seen that of the 61 babies who were breastfed, most babies were given substitute of breast milk as many as 45 babies (74\%), while the babies who were given exclusive breast milk were only 16 babies ( $26 \%$ ).

According to (IDAI, 2010) BREAST MILK is the most important source that every baby needs, ideally given exclusively for 6 months and continued with complementary foods until the age of 2 years. WHO (World Health Organization) states that exclusive breast milk is breast milk without other fluids, including formula, water, lemon juice, or other additional foods until the baby is 6 months old. While the statement (Widuri, 


\section{STRADA Jurnal Ilmiah Kesehatan}

DOI: $10.30994 /$ sjik.v9i2.334

ISSN: 2252-3847 (print); 2614-350X (online)

Vol.9 No.2 November 2020 Page.1567-1574

2013) exclusive breast milk is breast milk from a mother to her baby who is given without drinking or other food, including water or other additional vitamins.

The facts in the research place showed that there are still many babies who do not get exclusive breast milk, meaning that most babies are given additional food such as formula milk. As explained (IDAI, 2013) that breast milk is the most important source needed by every baby and ideally given exclusively for 6 months. By the facts and existing theories, the majority of mothers' education is high school. In the secondary education category, this can affect the knowledge of mothers about exclusive breast milk, so that exclusive breast milk is only a small part, namely $26 \%$. A good mother's knowledge about exclusive breast milk will not automatically affect the emergence of a positive attitude, even the practice of exclusive breast milk. This is because a mother will first give exclusive breast milk based on her very supportive attitude towards exclusive breast milk. This attitude arises because of considerations according to their analysis. This is by Ajzen's theory which assumes that people will consider the advantages and disadvantages of behavior according to their analysis (Raharjo, 2015).

\section{B. Rough Motor Development in Infants aged 6-9 Months in Karangtalun Village, Kalidawir District, Tulungagung Regency in 2019}

Based on table 2 it shows that of the 61 babies, most of them had dubious rough motor development, as many as 33 babies $(54.1 \%)$.

Rough motor development is body movement that uses large muscles or a large part of the body which is affected by the maturity of the child himself. Rough motor skills in infants aged 6-9 months include crawling, pulling to a standing position, holding hands, and walking with assistance. In infants aged 6-9 months, the rough motor skills vary. Based on the research site, some babies have motor development that is not according to their age. When the baby is 9 months old, the baby should be able to start walking by holding on to objects. However, the fact is that the baby has not reached this ability. This shows the baby has questionable rough motor development. Motor development in infants is influenced by several factors, one of which is nutrition. Good nutrition for babies is breast milk because breast milk contains all the nutrients that babies need for the process of growth and development. The location of the study shows that breast milk is still low, it is shown by the research data that most of the babies get substitute of breast milk namely 45 babies $(74 \%)$. This resulted in the stunted motor development of the baby so that when the research was conducted the results were doubtful.

\section{Fine Motor Development in Infants Aged 6-9 Months in Karangtalun Village, Kalidawir District, Tulungagung Regency in 2019}

Based on table 3 shows that of 61 babies, most of them have normal fine motor development, namely 35 babies (57.4\%), but some babies still 26 babies (42.6\%) had doubtful fine motor development.

Fine motor skills in infants aged 6-9 months include inserting objects into containers, playing gendering, holding stationary and scribbling, playing with toys that float in water, making sounds, hiding and looking for toys. In infants aged 6-9 months, their fine motor skills vary. Based on the research site, some babies have motor development that is not according to their age. When the baby is 6 months old, the baby should be able to imitate words. However, the fact is that the baby has not reached this ability. This shows the baby has questionable fine motor development. Motor 


\section{STRADA Jurnal Ilmiah Kesehatan}

DOI: $10.30994 /$ sjik.v9i2.334

ISSN: 2252-3847 (print); 2614-350X (online)

Vol.9 No.2 November 2020 Page.1567-1574

development in infants is influenced by several factors, one of which is nutrition. Good nutrition for babies is breast milk because breast milk contains all the nutrients that babies need for the process of growth and development. The location of the study shows that breast milk is still low, it is shown by the research data that most of the babies get substitute of breast milk namely 45 babies $(74 \%)$. This resulted in the stunted motor development of the baby so that when the research was conducted the results were doubtful.

\section{Breast milk in Rough Motor Development for Infants aged 6-9 months in Karangtalun Village, Kalidawir District, Tulungagung Regency in 2019}

Based on the research it is known that of the 16 babies who are given exclusive breast milk all babies have normal fine motor development, namely 16 babies (100\%). Meanwhile, out of 45 babies who were given SUBTITUTE OF BREAST MILK only 12 babies (26.7\%) had normal fine motor development.

The results of the test have Chi-square a significant value of $p$-value $=0.000$ where the value is smaller than $\alpha=0.05$, so $\mathrm{H}_{0}$ is rejected and $\mathrm{H}_{1}$ is accepted, so there is a relationship between breast milk and rough motor development in infants aged 6-9 months in the village. Karangtalun, Kalidawir District, Tulungagung Regency.

Based on the results of research conducted by researchers, it was shown that most babies aged 6-9 months had dubious rough motor development, as many as 33 babies $(54.1 \%)$. This shows the rough motor development of infants aged 6-9 months in Karangtalun Village, Kalidawir District, Tulungagung Regency is low.

E. Giving breast milk in Fine Motoric Development for Infants aged 6-9 Months in Karangtalun Village, Kalidawir District, Tulungagung Regency in 2019

Based on the research it is known that out of 16 babies who are given exclusive breast milk all babies have normal fine motor development, as many as 16 babies (100\%). Meanwhile, out of 45 babies who were given substitute of breast milk only 19 babies $(42.2 \%)$ had normal fine motor development.

The results of the test have Chi-square a significant value of $p$-value $=0.000$ where the value is smaller than $\alpha=0.05$, so $\mathrm{H}_{0}$ is rejected and $\mathrm{H}_{1}$ is accepted, so there is a relationship between breast milk and fine motor development in infants aged 6-9 months in the village. Karangtalun, Kalidawir District, Tulungagung Regency.

One important aspect of the development process is motor development because motor development is the beginning of intelligence. Intelligence that is seen early from the child is fine motor development. According to (Soetjiningsih, 2012), fine motor development is a movement that involves only certain motor parts and is carried out by small muscles but requires careful coordination. Based on research conducted by researchers, most babies aged 6-9 months still had questionable fine motor development, as many as 26 babies $(42.6 \%)$. This shows that the level of fine motor development in infants aged 6-9 months is classified as low. Many factors influence children's motor development, one of which is the duration of breast milk. According to theory (Haryono and Setianingsih, 2014), exclusive breast milk can make babies develop well in the first six months to more than six months of age. Based on research by (Ali, et al, 2014), children who received exclusive breast milk for 6 months had a higher ASQ (Ages and Stages Questionnaire) score with a p-value (0.004) in the rough motoric sector compared to children who do not get exclusive breast milk with p-value (0.091), so it can be concluded that exclusive breast milk plays an important role in 


\section{STRADA Jurnal Ilmiah Kesehatan}

DOI: $10.30994 /$ sjik.v9i2.334

ISSN: 2252-3847 (print); 2614-350X (online)

Vol.9 No.2 November 2020 Page.1567-1574

child development, especially in motor development. The results of this study were also supported by researchers (Nahari, 2015), in his study of 15 children who were given exclusive breast milk, $93.8 \%$ had more appropriate fine motor development than those who were not given exclusive breast milk with a percentage of $87.5 \%$ of 21 babies.

Based on the theory, research results, and previous studies, it is concluded that the pattern of breast milk affects the fine motor development of the baby because the nonexclusive breast milk pattern causes the baby's motor development to be imperfect and gets dubious results. The results of the study were that when the baby was 0-6 months old, the majority of parents had already given additional food to their babies. This causes the baby to not be able to achieve optimal development because it is hampered by nonexclusive breast milk.

\section{CONCLUSION}

There were 45 babies (74\%) who received SUBTITUTE OF BREAST MILK while 16 babies $(26 \%)$ received exclusive breast milk.

Rough motor development of infants aged 6-9 months in Karangtalun Village, Kalidawir District, Tulungagung Regency is doubtful, as many as 33 babies (54.1\%).

The fine motor development of infants aged 6-9 months in Karangtalun Village, Kalidawir District, Tulungagung Regency is normal, 35 babies (57.4\%), and some babies have dubious fine motor development, namely 26 babies $(42.6 \%)$.

The statistical test shows that there is a relationship between breast milk and rough motoric development in infants aged 6-9 months in Karangtalun Village, Kalidawir District, Tulungagung Regency in 2019 with the statistical test Chi-Square obtained a significant value of $p=0.000<\alpha=0.05$, which means $\mathrm{H}_{0}$ rejected and $\mathrm{H}_{1}$ accepted.

The statistical test shows that there is a relationship between breast milk and fine motoric development in infants aged 6-9 months in Karangtalun Village, Kalidawir District, Tulungagung Regency in 2019 with the statistical test Chi-Square obtained a significant value of $p=0.000<\alpha=0.05$, which means $\mathrm{H}_{0}$ rejected and $\mathrm{H}_{1}$ accepted.

\section{REFERENCES}

Ali, et.al., 2014. The Impact of Nutrition on Child Development at 3 Years in a Rural Community of India. International Journal of Prevenive Medicine, vol 5, no 4

Budi Raharjo. Mei 2015. Mudah Belajar C\#( Pemograman C\# dan Visual C\#) Informatika Bandung

Haryono R, Setianingsih, S. 2014. Manfaat Asi Eksklusif Untuk Buah Hati Anda.

Yogyakarta: Gosyen Publising

Husniati, A. 2007 Beberapa Faktor Yang Berhubungan Dengan Perkembangan Motorik Anak Usia 15-36 Bulan Di Desa Gajah Kecamatan Gajah Kabupaten Demak. Tesis

IDAI. (2010). Buku Ajar Hematologi- Onkologi Anak. Jakarta : EGC

Laksana. (2011). Referensi Ilmu Kebidanan Dan Keperawatan: Konsep Dasar Pola Asuh Gizi

Marimbi. 2010.Tumbuh Kembang, Status Gizi dan Imunisasi Dasar pada Balita. Yogyakarta : Nuha Medika

Nahari, 2015. The Relation Between Climate Variation And The Incidence Of Diarrhea In Semarang 2011-2015 (Case Study In Working Area Of Puskesmas Bandarharjo Semarang)

Nursalam. 2013. Konsep \& Penerapan Metodologi Penelitian Ilmu Keperawatan. Jakarta : Salemba Medika. 


\section{STRADA Jurnal Ilmiah Kesehatan}

DOI: $10.30994 /$ sjik.v9i2.334

ISSN: 2252-3847 (print); 2614-350X (online)

Vol.9 No.2 November 2020 Page.1567-1574

Profil Dinas Kesehatan Jawa Timur 2016, Seksi Pelayanan Kesehatan Primer Dinkes Jatim Soetjiningsih \& Ranuh, 2013. Tumbuh kembang anak edisi 2. Jakarta. Penerbit: Buku kedokteran EGC 2013

Soetjiningsih., 2012. Tumbuh Kembang Anak. Jakarta: EGC

Wiji, R.N. (2013). ASI dan Pedoman Ibu Menyusui. Yogyakarta: Nuha Medika

World Health Organization (WHO) 2005, The World Health Report 2005, make every mother and child count

Yuliarti, N. 2010. Keajaiban ASI: Makanan Terbaik untuk Kesehatan, Kecerdasan dan Kelincahan Si Kecil. Yogyakarta: And 